\title{
ANALISIS GOOD CORPORATE GOVERNANCE PADA KOPERASI
}

\author{
Tony Soebijono \\ Program Studi Akuntansi \\ Institut Bisnis dan Informatika Stikom Surabaya \\ Jalan Raya Kedung Baruk 98, Surabaya \\ Martinus Sony Erstiawan \\ Program Studi Akuntansi \\ Institut Bisnis dan Informatika Stikom Surabaya \\ Jalan Raya Kedung Baruk 98, Surabaya \\ Lilis Binawati \\ Program Studi Akuntansi \\ Institut Bisnis dan Informatika Stikom Surabaya \\ Jalan Raya Kedung Baruk 98, Surabaya
}

\begin{abstract}
In the 1945 Constitution of the State of the Republic of Indonesia there is a chapter that makes the foundation of the establishment and development of Koperasi in Indonesia. Article 33 of the 1945 Constitution of the State of the Republic of Indonesia states that the economy is constituted as a joint effort based on the principle of kinship. In order for Koperasi to develop properly, it is necessary to have a Good Corporate Governance (GCG). To be able to have good governance, then in managing Koperasi there must be transparency, independence, accountability, responsibility, fairness and equality which are the basic principles in good organizational management. This research will try to observe whether Koperasi has implemented the basic principles of Good Corporate Governance (GCG). The research was conducted at Koperasi Pegawai in Surabaya by using research and development approach and descriptive data analysis. The results of data processing show that the principle of transparency obtained index 3.25 can be implemented well which indicated by financial reporting that has been audited by Public Accounting Firm (KAP) for 8 years. The principle of independence obtained index 3.71 is quite manifest in its management. The principle of accountability with the 3.00 index can be implemented well, as indicated by the presence of AD/ART (Anggaran Dasar/Anggaran Rumah Tangga), vision, mission and purpose of the establishment of Koperasi which all refer to Act Number 25 Year 1992. The rules are implemented and conditioned according to the conditions of the Koperasi. The principle of responsibilitas with index 2.71 also can be done well, with the obedience to the regulation of Act Number 25 Year 1992 which is part of responsibility of management and member of Koperasi in execution of duty. The principle of fairness and equality with the 3.43 index is well executed, there is no
\end{abstract}


discrimination due to differences in ethnicity, religion, race, class, gender and physical condition.

\begin{abstract}
ABSTRAK
Dalam Undang-Undang Dasar Negara Republik Indonesia Tahun 1945 terdapat pasal yang menjadikan dasar berdiri dan berkembangnya koperasi di Indonesia. Pasal 33 Undang-Undang Dasar Negara Republik Indonesia Tahun 1945 menyatakan perekonomian disusun sebagai usaha bersama berdasar atas asas kekeluargaan. Agar koperasi dapat berkembang dengan baik, maka perlu adanya suatu tata kelola organisasi yang baik (Good Corporate Governance/GCG). Untuk dapat memiliki tata kelola yang baik, maka dalam mengelola koperasi harus ada transparansi, independensi, akuntabilitas, responsibilitas, kewajaran dan kesetaraan yang merupakan prinsip-prinsip dasar dalam pengelolaan organisasi yang baik. Penelitian ini akan coba mengamati apakah koperasi telah mengimplementasikan prinsip-prinsip dasar tata kelola organisasi yang baik (Good Corporate Governance/GCG). Penelitian dilakukan pada Koperasi Pegawai di Surabaya dengan menggunakan pendekatan research and development dan analisis data deskriptif. Hasil pengolahan data menunjukkan bahwa prinsip transparansi memperoleh indeks 3,25 dapat dilaksanakan dengan baik yang ditunjukkan dengan pelaporan keuangan yang telah diaudit oleh Kantor Akuntan Publik (KAP) selama 8 tahun belakangan. Prinsip independensi memperoleh indeks 3,71 cukup terwujud dalam pengelolaannya. Prinsip akuntabilitas dengan indeks 3,00 dapat terlaksana dengan baik, yang ditunjukkan dengan adanya AD/ART (Anggaran Dasar/Anggaran Rumah Tangga), visi, misi dan tujuan berdirinya koperasi yang kesemuanya mengacu pada Undang-Undang Nomor 25 Tahun 1992. Aturan tersebut dilaksanakan dan dikondisikan sesuai kondisi koperasi. Prinsip responsibilitas dengan indeks 2,71 juga dapat terlaksana dengan baik, dengan adanya ketaatan terhadap Undang-Undang Nomor 25 Tahun 1992 yang merupakan bagian dari tanggungjawab pengurus maupun anggota koperasi dalam pelaksanaan tugas. Prinsip kewajaran serta kesetaraan dengan indeks 3,43 terlaksana dengan baik, tidak ada perlakuan diskriminasi karena perbedaan suku, agama, ras, golongan, gender dan kondisi fisik.
\end{abstract}

Keywords: Koperasi, Good Corporate Governance

\section{PENDAHULUAN}

Koperasi berlandaskan Undang-Undang Dasar Negara Republik Indonesia Tahun 1945 dengan tujuan untuk memberdayakan pengusaha kecil dan menengah agar menjadi pelaku ekonomi yang tangguh dan profesional dengan mengembangkan sistem ekonomi kerakyatan yang bertumpu pada mekanisme pasar yang berbasis Sumber Daya Alam dan Sumber Daya Manusia yang produktif, mandiri, maju, berdaya saing, berwawasan lingkung- 
an dan berkelanjutan dengan bermuara dalam koperasi.

Koperasi tidak serta merta semuanya dapat berkembang dengan baik, permasalahan demi permasalahan diantaranya orientasi strategi dalam menggerakkan koperasi yang masih kurang konsisten dalam menghimpun dan memobilisasikan berbagai sumber daya yang diperlukan untuk memanfaatkan peluang usaha yang ada. Terdapat kendala dalam pengelolaan koperasi diantaranya tidak memiliki kekuatan anggota dalam menentukan arah koperasi, tidak memiliki modal yang cukup, tidak memiliki anggota yang kompeten dalam bidang manajemen, tidak memiliki tata kelola yang baik, dan kualitas koperasi masih beragam dalam pengembangan strategi kerjasama dengan pihak luar dan pihak lain, bahkan kinerja manajemen yang masih kurang.

Pengelolaan manajemen koperasi harus didasarkan pada visi, misi, tujuan dan aturan yang berlaku, diantaranya AD/ART (Anggaran Dasar/ Anggaran Rumah Tangga) dan kebijakan organisasi yang mengacu pada Undang-Undang Nomor 25 Tahun 1992 tentang Perkoperasian. Koperasi juga harus memiliki struktur organisasi yang menggambarkan peran dan fungsi masing-masing personil sesuai dengan jobdesk dari para pengurus, pengawas dan anggota yang dilakukan secara tersistem dalam menjalankan koperasi yang berlandaskan tata kelola yang baik (Good Corporate Governance/GCG), yaitu memenuhi prinsip: transparan, mandiri, akuntabilitas, responsibilitas, kewajaran dan kesetaraan.

Penelitian ini bertujuan mengkaji implementasi penerapan Good Corporate Governance (GCG) pada Koperasi Pegawai di Surabaya, dalam rangka untuk memberikan informasi yang valid dan akurat kepada stakeholder mengenai profil implementasi Good Corporate Governance (GCG) pada koperasi.

\section{TINJAUAN PUSTAKA}

Menurut Tambunan (2008) kegiatan koperasi yang diselenggarakan saat ini berasal dari dorongan pemerintah. Dengan memiliki perangkat koperasi yang baik dapat dikelola koperasi yang menjadikan wadah bagi anggota. Menurut Tejo (2008) rapat anggota merupakan wadah aspirasi anggota dan pemegang kekuasaan tertinggi dalam koperasi. Segala kebijakan yang berlaku dalam koperasi harus melewati persetujuan rapat anggota terlebih dahulu, termasuk, pengangkatan dan pemberhentian personalia pengurus dan pengawas. Dalam Undang-Undang Nomor 25 Tahun 1992 tentang Perkoperasian, Bab IV tentang perangkat koperasi pasal 21 disebutkan bahwa perangkat organisasi koperasi terdiri dari rapat anggota, pengurus dan pengawas. Pasal 22 menyebutkan rapat anggota merupakan pemegang kekuasaan tertinggi dalam koperasi dan rapat anggota dihadiri oleh semua anggota yang pelaksanaannya diatur di dalam AD (Anggaran Dasar).

Dengan tata kelola yang baik $(G C G)$, koperasi akan dapat menambah kepercayaan dari publik. Rakhmat dan Saraswati (2013) mengatakan bahwa $G C G$ merupakan tata kelola perusahaan yang memiliki agenda yang lebih luas lagi di masa yang akan datang. Untuk penciptaan pasar dengan dukungan $G C G$ dibutuhkan pilar untuk menjadi pasar yang memiliki efektifitas dan efisiensi serta berkelanjutan berdasarkan peraturan perundangan-undangan sesuai dengan pedo- 
man menurut KNKG (Komite Nasional Kebijakan Governance) (2006), yaitu: a) negara dan perangkatnya sebagai regulator; b) dunia usaha sebagai pelaku pasar; c) masyarakat sebagai pengguna. Pilar tersebut dapat menjadi prinsip dasar $G C G$ dalam tata kelola. Menurut KNKG (2006): (1) negara dan perangkatnya menciptakan peraturan perundang-undangan yang menunjang iklim usaha yang sehat, efisien dan transparan, melaksanakan peraturan perundang-undangan dan penegakan hukum secara konsisten; (2) dunia usaha sebagai pelaku pasar menerapkan GCG sebagai pedoman dasar pelaksanaan usaha; (3) masyarakat sebagai pengguna produk dan jasa dunia usaha serta pilar yang terkena dampak dari keberadaan perusahaan, menunjukkan kepedulian dan melakukan kontrol sosial secara obyektif dan bertanggungjawab.

Menurut Kaihatu (2006) prinsip GCG yaitu: 1) Transparency (Keterbukaan Informasi) merupakan keterbukaan dalam melaksanakan proses pengambilan keputusan dan keterbukaan dalam mengemukakan informasi materiil dan relevan mengenai perusahaan. 2) Accountability (Akuntabilitas) merupakan kejelasan fungsi, struktur, sistem dan pertanggungjawaban organ perusahaan, sehingga pengelolaan perusahaan terlaksana secara efektif. 3) Responsilbility (Responsibilitas) merupakan kesesuaian (kepatuhan) di dalam pengelolaan perusahaan terhadap prinsip korporasi yang sehat serta peraturan perundangan yang berlaku. 4) Independency (kemandirian) merupakan keadaan di mana perusahaan dikelola secara profesional tanpa benturan kepentingan dan pengaruh/ tekanan dari pihak manajemen yang tidak sesuai dengan peraturan dan perundang-undangan yang berlaku dan prinsip-prinsip korporasi yang sehat. 5) Fairness (Kesetaraan dan Kewajaran) merupakan perlakuan yang adil dan setara di dalam memenuhi hak-hak stakeholder yang timbul berdasarkan perjanjian serta peraturan perundangan yang berlaku.

Menurut Aldridge dan Sutojo dalam Ferlinda (2008) tujuan penerapan $G C G$ yaitu: (a) melindungi hak dan kepentingan pemegang saham; (b) melindungi hak dan kepentingan para anggota stakeholder non pemegang saham; (c) meningkatkan nilai perusahaan dan para pemegang saham; (d) meningkatkan efisiensi dan efektifitas kerja dewan pengurus atau Board of Director dan manajemen perusahaan; dan (e) meningkatkan mutu hubungan Board of Directors dengan manajemen senior perusahaan. Sedangkan manfaat GCG menurut Wati (2012) diantaranya: a) perusahaan dapat membenahi faktor-faktor internal organisasinya yang belum sesuai dan belum mendukung terwujudnya $G C G$ berdasarkan hasil temuan selama survei CGPI berlangsung; b) peningkatan kepercayaan investor dan publik terhadap perusahaan karena adanya hasil publikasi IICG tentang pelaksanaan konsep $C G$ yang dilakukan perusahaan; c) peningkatan kesadaran bersama di kalangan internal perusahaan dan stakeholder terhadap pentingnya $G C G$ dalam pengelolaan perusahaan ke arah pertumbuhan yang berkelanjutan; d) pemetaan masalah-masalah strategis yang terjadi di perusahaan dalam penerapan GCG sebagai masukan dalam penyusunan kebijakan yang diperlukan; e) Corporate Governance Perseption Index (CGPI) saat dijadikan sebagai indikator atau standar mutu yang ingin dicapai perusahaan 
dalam bentuk pengakuan dari masyarakat terhadap penerapan prinsip $G C G$; f) perwujudan komitmen dan tanggungjawab bersama serta upaya yang mendorong seluruh anggota organisasi perusahaan untuk menerapkan $G C G$.

Mekanisme Corporate Governance diarahkan untuk menjamin dan mengawasi berjalannya sistem Governance dalam sebuah organisasi (Arifin, 2005 dalam Purno, 2013). Budiono (2005) dalam Purno (2013) mengatakan bahwa mekanisme Corporate Governance merupakan suatu sistem yang mampu mengendalikan dan mengarahkan kegiatan operasional perusahaan serta pihak-pihak yang terlibat di dalamnya, sehingga dapat digunakan untuk menekan terjadinya masalah agency. Lastanti (2004) dalam Purno (2013) mengatakan bahwa mekanisme pengawasan Corporate Governance dibagi dalam dua kelompok diantaranya mekanisme internal dan eksternal. Mekanisme internal merupakan cara untuk mengendalikan perusahaan dengan menggunakan struktur dan proses internal seperti rapat umum pemegang saham, komposisi dewan direksi, komposisi dewan komisaris dan pertemuan dengan Board of Director. Sedangkan mekanisme eksternal merupakan cara mempengaruhi perusahaan selain dengan menggunakan mekanisme internal, seperti pengendalian perusahaan dan mekanisme pasar.

$G C G$ tidak hanya berperan dalam pengembangan perusahaan yang memiliki badan hukum baik dari pemerintahan atau pun dari perusahaan perseroan. Prinsip GCG secara langsung dapat menjadi bagian dalam pengembangan bidang apapun untuk mencapai kondisi perusahaan yang berkembang dan dapat bersaing dengan tata kelola yang baik. Pengurus koperasi, anggota serta masyarakat dapat menggunakan prinsip keterbukaan informasi mengetahui kondisi, keputusan, perkembangan koperasi, rencana pengembangan koperasi dan lainlain. Prinsip akuntabilitas di mana masyarakat dapat secara langsung memahami fungsi, tanggungjawab, job desk melalui struktur organisasi, sistem yang dimiliki dan perkembangannya, serta pertanggungjawaban keuangan kepada seluruh anggota koperasi. Pada prinsip responsibilitas koperasi dapat menerapkan kepatuhan koperasi terhadap peraturan pemerintah yang berlaku termasuk pada unsur pajak, ketenagakerjaan, jaminan keuangan, kesehatan dan keselamatan kerja. Pada prinsip kemandirian, pengelolaan koperasi dapat dikelola dengan baik dan profesional dan tanpa tekanan dari pihak manapun. Prinsip kesetaraan serta kewajaran pada koperasi menyatakan perlakuan yang sama tanpa perbedaan karena unsur SARA, kondisi fisik maupun gender akan diterapkan terhadap semua orang. Dengan menerapkan prinsip-prinsip ini diharapkan koperasi dapat lebih berkembang dan berdaya saing.

\section{METODE PENELITIAN}

Penelitian ini merupakan penelitian deskriptif analitik yang bertujuan untuk mengkaji implementasi Good Corporate Governance pada Koperasi Pegawai di Surabaya. Metode pengumpulan data dilakukan melalui wawancara dengan pengurus dan menyebar kuesioner kepada anggota.

\section{HASIL PENELITIAN}

Dalam penelitian ini tidak semua data yang didapatkan dari hasil 
pengisian kuesioner oleh responden dikatakan layak untuk diproses lebih lanjut. Data dari hasil penyebaran kuesioner dikatakan tidak layak, jika ada butir pertanyaan yang tidak dijawab atau pengisiannya tidak sesuai dengan petunjuk yang telah ditentukan. Sehingga data kuesioner tersebut tidak dapat diolah lebih lanjut. Jika semua butir pertanyaan yang ada dijawab sesuai dengan cara pengisian kuesioner, maka data kuesioner tersebut dikatakan layak sehingga dapat diolah lebih lanjut.

Dari 75 kuesioner yang disebar, terdapat 65 kuesioner yang layak untuk diolah pada proses selanjutnya sedangkan sisanya dianggap tidak layak untuk diolah lebih lanjut. Hasil pemetaan ini dapat dijadikan dasar bagi pihak manajemen untuk mengukur proses yang ada saat ini dan mencari tahu apa yang diperlukan untuk meningkatkannya. Hasil ringkasan kuesioner dapat dilihat pada Tabel 1

Tabel 1

Ringkasan Hasil Kuesioner

\begin{tabular}{|l|c|c|c|c|}
\hline \multicolumn{1}{|c|}{ Lingkup } & $\begin{array}{c}\sum \\
\text { Jaw aban }\end{array}$ & $\begin{array}{c}\sum \\
\text { Pertanyaan }\end{array}$ & Indeks & $\begin{array}{c}\text { Tingkat } \\
\text { Model }\end{array}$ \\
\hline Independen & 26 & 7 & 3.71 & 4 \\
\hline Transparansi & 26 & 8 & 3.25 & 3 \\
\hline Responsibilitas & 17 & 7 & 2.71 & 3 \\
\hline Akuntabilitas & 24 & 8 & 3.00 & 3 \\
\hline $\begin{array}{l}\text { Kew ajaran \& } \\
\text { Kesetaraan }\end{array}$ & 24 & 7 & 3.43 & 3 \\
\hline
\end{tabular}

Berdasarkan hasil rekapan angket kuesioner tersebut tingkat model angka 3 lebih banyak dihasilkan berdasarkan indeks masing-masing lingkup $G C G$.

\section{PEMBAHASAN DAN ANALISIS DATA}

Penilaian berdasarkan perwujudan implementasi Good Corporate
Governance. (GCG) dari hasil penyebaran angket kuesioner

Tabel 2

Rekapitulasi Angket Kuesioner

Transparansi

\begin{tabular}{|c|c|c|c|c|c|c|c|c|}
\hline & \multicolumn{7}{|c|}{ Pertanyaan No. } \\
\hline Jawaban & 1 & 2 & 3 & 4 & 5 & 6 & 7 & 8 \\
\hline 1 & 0 & 0 & 0 & 0 & 0 & 0 & 0 & 0 \\
\hline 2 & 0 & 4 & 61 & 0 & 13 & 0 & 0 & 7 \\
\hline 3 & 10 & 59 & 3 & 52 & 27 & 3 & 0 & 56 \\
\hline 4 & 53 & 2 & 1 & 11 & 25 & 49 & 60 & 2 \\
\hline 5 & 2 & 0 & 0 & 2 & 0 & 13 & 5 & 0 \\
\hline
\end{tabular}

Tabel 3.

Rekapitulasi Jawaban Kuesioner Transparansi

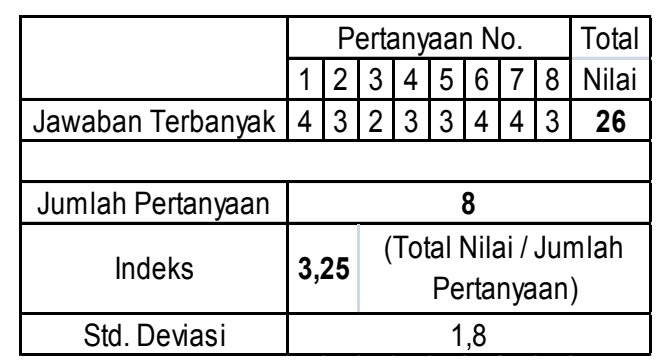

Berdasarkan perhitungan di atas diperoleh persentasi secara keseluruhan sama dengan indeks 3,25 dan dapat ditarik kesimpulan bahwa prinsip transparansi dapat terlaksana dengan baik.

Prinsip transparansi Koperasi Pegawai dapat terlaksana dengan baik sesuai dengan prinsip transparansi yang dimiliki oleh KNKG (2006), di mana dalam melakukan transparansi atas informasi yang ada, termasuk laporan keuangan dapat dilaksanakan dengan baik, tepat waktu, memadai, jelas dan dapat diperbandingkan dengan laporan keuangan tahun lalu dan dengan mudah dapat diakses oleh pemangku kepentingan. Langkah transparansi dapat mendukung kebijakan dan pedoman yang baik di mana semua unsur (pengurus) dapat meng- 
kondisikan dan terus-menerus melakukan pengembangan usaha yang dapat dinikmati oleh seluruh anggota dengan menyampaikan secara jelas dan transparan berkaitan dengan kondisi keuangan, strategi perusahaan, SHU (Sisa Hasil Usaha) anggota.

\section{Tabel 4}

Rekapitulasi Angket Kuesioner Independensi (Kemandirian)

\begin{tabular}{|c|c|c|c|c|c|c|c|}
\hline \multirow{3}{*}{ Jawaban } & \multicolumn{7}{|c|}{ Pertanyaan No. } \\
\cline { 2 - 8 } & $\mathbf{1}$ & $\mathbf{2}$ & $\mathbf{3}$ & $\mathbf{4}$ & $\mathbf{5}$ & $\mathbf{6}$ & $\mathbf{7}$ \\
\hline 1 & 1 & 0 & 0 & 0 & 0 & 0 & 0 \\
\hline 2 & 1 & 0 & 14 & 6 & 19 & 0 & 0 \\
\hline 3 & 9 & 20 & 38 & 54 & 34 & 6 & 1 \\
\hline 4 & 50 & 24 & 11 & 5 & 11 & 39 & 9 \\
\hline 5 & 4 & 21 & 2 & 0 & 1 & 20 & 55 \\
\hline
\end{tabular}

Tabel 5

Rekapitulasi Hasil Kuesioner Independensi (Kemandirian)

\begin{tabular}{|c|c|c|c|c|c|c|c|c|}
\hline & \multicolumn{7}{|c|}{ Total } \\
\cline { 2 - 9 } & 1 & 2 & 3 & 4 & 5 & 6 & 7 & Nilai \\
\hline$\sum$ Terbanyak & 4 & 4 & 3 & 3 & 3 & 4 & 5 & $\mathbf{2 6}$ \\
\hline$\sum$ Pertanyaan & \multicolumn{10}{|c|}{7} \\
\hline Indeks & 3,71 & (Total Nilai / Jumlah Pertanyaan) \\
\hline Std Deviasi & \multicolumn{1}{|c|}{1,9} \\
\hline
\end{tabular}

Berdasarkan hasil perhitungan angket kuesioner dengan nilai indeks 3,71 dengan tingkat Model Maturity dan kriteria 4, maka dapat dikatakan $G C G$ cukup terwujud dan dapat dikelola dengan baik.

Pada prinsip $G C G$ menurut KNKG (2006) agar dapat melaksanakan dan dikelola dengan baik pihak yang terkait dalam hal ini pengurus, anggota dan pengelola secara independen melaksanakan tugas dan tidak saling mendominasi dan tidak diintervensi oleh pihak lain, bebas benturan kepentingan, dan bebas tekanan. Dengan begitu koperasi dapat melaksanakan fungsi dan tugasnya dengan baik sesuai Rapat Anggaran Tahunan
(RAT) dan Rapat Kerja Rencana Anggaran Pendapatan dan Belanja (RKRAPB) untuk dapat dilakukan atas rencana yang disusun.

\section{Tabel 6}

Rekapitulasi Angket Kuesioner Tanggungjawab (Akuntabilitas)

\begin{tabular}{|c|c|c|c|c|c|c|c|c|}
\hline \multirow{2}{*}{ Jawaban } & \multicolumn{10}{|c|}{ Pertanyaan No. } \\
\cline { 2 - 9 } & $\mathbf{1}$ & $\mathbf{2}$ & $\mathbf{3}$ & $\mathbf{4}$ & $\mathbf{5}$ & $\mathbf{6}$ & $\mathbf{7}$ & $\mathbf{8}$ \\
\hline 1 & 15 & 1 & 9 & 0 & 0 & 0 & 0 & 0 \\
\hline 2 & 49 & 12 & 52 & 7 & 5 & 0 & 0 & 0 \\
\hline 3 & 1 & 52 & 4 & 58 & 55 & 4 & 4 & 32 \\
\hline 4 & 0 & 0 & 0 & 0 & 5 & 61 & 61 & 30 \\
\hline 5 & 0 & 0 & 0 & 0 & 0 & 0 & 3 & 3 \\
\hline
\end{tabular}

Tabel 7

Rekapitulasi Hasil Kuesioner Tanggungjawab (Akuntabilitas)

\begin{tabular}{|c|c|c|c|c|c|c|c|c|c|}
\hline & \multicolumn{8}{|c|}{ Pertanyaan No. } & Total \\
\hline & 1 & 2 & 3 & 4 & 5 & 6 & 7 & 8 & Nilai \\
\hline$\sum$ Terbanyak & 2 & 3 & 2 & 3 & 3 & 4 & 4 & 3 & 24 \\
\hline$\sum$ Pertanyaan & \multicolumn{8}{|c|}{8} & \\
\hline Indeks & \multicolumn{9}{|c|}{$3, \mathbf{0 0}$ stal Nilai / Jumlah Pertanya } \\
\hline Std Deviasi & \multicolumn{9}{|c|}{1,73} \\
\hline
\end{tabular}

Berdasarkan hasil angket kuesioner dengan prinsip $G C G$ mengenai akuntabilitas dengan mengajukan 8 pertanyaan dengan total nilai berdasarkan jawaban terbanyak berjumlah 24 dan memiliki indeks 3,00. Dari hasil tersebut menurut kriteria berada pada nilai 3 yaitu terdefinisi dengan kriteria dapat terlaksana dengan baik.

Prinsip akuntabilitas yang terdapat di koperasi di mana pengurus dan anggota memiliki tanggungjawab masing-masing yang secara transparan diatur dalam AD/ART dan dikerjakan serta dilakukan secara wajar, sehingga kesinambungan dan perkembangan koperasi dapat serta merta melayani masyarakat melalui toko serbaguna dengan harga yang lebih murah dibanding mini market. 
Tabel 8

Rekapitulasi Angket Kuesioner

Responsibilitas

\begin{tabular}{|c|c|c|c|c|c|c|c|}
\hline \multirow{2}{*}{ Jawaban } & \multicolumn{7}{|c|}{ Pertanyaan No. } \\
\cline { 2 - 8 } & $\mathbf{1}$ & $\mathbf{2}$ & $\mathbf{3}$ & $\mathbf{4}$ & $\mathbf{5}$ & $\mathbf{6}$ & $\mathbf{7}$ \\
\hline 1 & 16 & 0 & $\mathbf{4}$ & 0 & 0 & 0 & 0 \\
\hline 2 & 46 & 7 & 15 & 54 & 0 & 0 & 0 \\
\hline 3 & 3 & 58 & 2 & 7 & 8 & 33 & 14 \\
\hline 4 & 0 & 0 & 0 & 0 & 54 & 30 & 41 \\
\hline 5 & 0 & 0 & 0 & 0 & 3 & 2 & 10 \\
\hline
\end{tabular}

Tabel 9

Rekapitulasi Hasil Kuesioner

Responsibilitas

\begin{tabular}{|c|c|c|c|c|c|c|c|c|}
\hline & \multicolumn{7}{|c|}{ Pertanyaan No. } & Total \\
\cline { 2 - 7 } & 1 & 2 & 3 & 4 & 5 & 6 & 7 & Nilai \\
\hline$\sum$ Terbanyak & 2 & 3 & 1 & 2 & 4 & 3 & 4 & 19 \\
\hline$\sum$ Pertanyaan & \multicolumn{8}{|c|}{7} \\
\hline$\sum$ Indeks & 2,71 & (Total Nilai / Jumlah Pertanyaan) \\
\hline Std. Deviasi & \multicolumn{1}{|c|}{1,65} \\
\hline
\end{tabular}

Dari hasil rekapitulasi angket kuesioner tentang responsibilitas terhadap koperasi di mana jawaban terbanyak dengan total nilai 19 dalam jumlah pertanyaan 7 dan hasilnya berupa nilai indeks dengan jumlah 2,71.

Berdasarkan prinsip $G C G$ tentang responsibilitas di mana perusahaan (koperasi) harus mematuhi peraturan perundang-undangan yang berlaku serta melaksanakan tanggungjawab terhadap masyarakat dan lingkungan, sehingga terpelihara keberlangsungan hidup secara berkesinambungan (terusmenerus) demi masa depan dan perkembangan koperasi dan tetap menjadi motor penggerak bagi masyarakat dalam memajukan perekonomian.

Tabel 10

Rekapitulasi Angket Kuesioner Kewajaran dan Kesetaraan (Fairness)

\begin{tabular}{|c|c|c|c|c|c|c|c|}
\hline \multirow{2}{*}{ Jawaban } & \multicolumn{7}{|c|}{ Pertanyaan No. } \\
\cline { 2 - 8 } & $\mathbf{1}$ & $\mathbf{2}$ & $\mathbf{3}$ & $\mathbf{4}$ & $\mathbf{5}$ & $\mathbf{6}$ & $\mathbf{7}$ \\
\hline 1 & 13 & 0 & 0 & 0 & 0 & 0 & 0 \\
\hline 2 & 52 & 2 & 4 & 0 & 0 & 0 & 3 \\
\hline 3 & 0 & 58 & 60 & 0 & 7 & 4 & 56 \\
\hline 4 & 0 & 5 & 1 & 4 & 57 & 57 & 6 \\
\hline 5 & 0 & 0 & 0 & 61 & 1 & 4 & 0 \\
\hline
\end{tabular}

Tabel 11

Rekapitulasi Hasil Kuesioner Kewajaran dan Kesetaraan (Fairness)

\begin{tabular}{|c|c|c|c|c|c|c|c|c|}
\hline & \multicolumn{7}{|c|}{ Pertanyaan No. } & Total \\
\cline { 2 - 8 } & 1 & 2 & 3 & 4 & 5 & 6 & 7 & Nilai \\
\hline$\sum$ Terbanyak & 2 & 3 & 3 & 5 & 4 & 4 & 3 & $\mathbf{2 4}$ \\
\hline$\sum$ Pertanyaan & \multicolumn{7}{|c|}{7} \\
\hline Indeks & 3,43 & tal Nilai / Jumlah Pertanya \\
\hline Std Deviasi & \multicolumn{1}{|c|}{1,85} \\
\hline
\end{tabular}

Dari hasil rekapitulasi angket kuesioner berdasarkan prinsip kewajaran dan kesetaraan (fairness) dengan 7 pertanyaan dengan jawaban terbanyak dengan total nilai 24 memiliki indeks 3,43. Dari hasil tersebut menurut tingkat Model Maturity dan kriteria terletak di angka 3 (tiga) yaitu terdefinisi dan terlaksana dengan baik.

Berdasarkan prinsip fairness (kewajaran dan kesetaraan) menurut KNKG (2016) koperasi harus senantiasa memperhatikan kepentingan anggota berdasarkan asas kewajaran dan kesetaraan. Di mana koperasi dapat memberikan kesempatan pada anggota untuk memberikan masukan dan pendapat terhadap perubahan yang terjadi dalam koperasi berdasarkan informasi yang ada dan menyampaikan secara transparan kegiatan yang telah dilakukan dan akan dilakukan.

\section{Aspek-Aspek Good Corporate Governance Transparansi}

Perwujudan prinsip transparansi telah dilakukan oleh Koperasi Pegawai dengan bersifat terbuka terhadap laporan keuangan dan diaudit oleh Kantor Akuntan Publik (KAP). Berdasarkan pasal 30 ayat (1d) Undang-Undang Nomor 25 Tahun 1992 sebelum laporan keuangan diaudit oleh KAP pengurus dapat mengajukan laporan keuangan dan per- 
tanggungjawaban dalam pelaksanaan tugas dan ayat (1e) pengurus menyelenggarakan pembukuan keuangan dan inventaris yang dilakukan secara tertib. Dengan dilakukannya audit atas laporan keuangan yang dilakukan KAP, maka dapat menciptakan nilai tambah bagi pihak yang berkepentingan diantaranya pengurus, anggota koperasi, investor maupun kreditor, serta prinsip koperasi ini telah diselenggarakan sesuai dengan pasal 40 dalam UndangUndang Nomor 25 Tahun 1992 di mana koperasi dapat meminta jasa audit kepada akuntan publik.

Berdasarkan hasil wawancara yang dilakukan kepada pengurus (bendahara): "Transparansi berkaitan dengan laporan keuangan diperiksa oleh Kantor Akuntan Publik (KAP) sejak 8 tahun yang lalu hingga sekarang. Saat itu masih diketuai oleh Bapak Yosua yang sekarang Rektor Universitas Widya Kartika. Hasil pemeriksaan laporan keuangan oleh $K A P$ diungkap secara transparan kepada para pengurus. Pada saat Rapat Anggota Tahunan yang dilakukan bulan Maret, KAP tidak hadir dan segala pertanyaan yang terjadi berkaitan dengan keuangan disampaikan secara transparan oleh pengurus. Pedoman Kerja pengurus sesuai dengan AD/ART. Masyarakat bisa melakukan pembelian pada usaha koperasi hanya tidak bisa melakukan simpan pinjam, bagi anggota koperasi yang melakukan simpan pinjam dalam pengembalian pinjamannya akan langsung dipotong dari gaji untuk melunasi".

Sedangkan hasil wawancara dengan manajer yang mengelola toserba (Toko Serba ada): "Laporan keuangan telah diaudit oleh Kantor Akuntan Publik. AD/ART merupakan pedoman kerja para pengurus dan tugas anggota yang diatur dan disesuaikan dengan Undang-Undang Nomor 25 Tahun 1992. Usaha Koperasi yang ada tidak menutup diri bagi masyarakat sekitar, masyarakat dapat membeli dan membayar barang atau pembayaran PLN, pulsa elektronik maupun tiket kereta yang berhubungan langsung dengan server PT. KAI. Masyarakat sekitar tidak dapat melakukan simpan pinjam hanya diperbolehkan membeli barang yang tersedia di swalayan".

Prinsip dasar transparansi berkaitan dengan kualitas yang disajikan berdasarkan informasi yang dibutuhkan oleh pengurus dan anggota koperasi dalam transparansi pengelolaan keuangan dan pembagian Sisa Hasil Usaha yang diberikan kepada anggota. Pasal 30 dalam Undang-Undang Nomor 25 Tahun 1992 yang isinya dapat menyelenggarakan pembukuan keuangan dan inventaris secara tertib. Untuk itu transparansi dilakukan dalam mengembangkan secara khusus dokumentasi sistem informasi akuntansi, sehingga transparansi dalam pengambilan kebijakan telah disesuaikan dengan prosedur dan kebijakan yang ada (Arifin, 2005). Sedangkan menurut Puspitasari dan Ludigdo (2013) penyediaan transparansi dengan kemudahan akses dan dapat dipahami berasal dari informasi dan kebijakan dalam perusahaan (koperasi).

Menurut Tadikapurry (2011: 63) wujud nyata transparansi dalam mendukung $G C G$ diantarnya keterbukaan dalam hal rapat-rapat, keterbukaan informasi, keterbukaan prosedur, keterbukaan register dan keterbukaan menerima peran serta masyarakat. Prinsip dari KNKG (2006) yang merupakan pedoman pelaksanaan $G C G$ 
telah diikuti oleh Koperasi Pegawai, di mana $\mathrm{AD} / \mathrm{ART}$ dan kebijakan telah disesuaikan dengan pedoman pelaksanaan $G C G$ dan informasi laporan keuangan oleh Koperasi Pegawai disediakan tepat waktu, memadai, jelas, akurat dan dapat diperbandingkan serta mudah diakses oleh pemangku kepentingan seperti yang diinginkan oleh pedoman pelaksanaan $G C G$.

Visi dan misi Koperasi Pegawai merupakan sikap yang dijunjung tinggi oleh para pengurus dan anggota. Misi koperasi adalah "Bersikap adil dan demokratis, serta bekerja secara transparan dan akuntabel". Dari misi yang ada terlihat bahwa bersama-sama memiliki rasa tanggungjawab, disiplin, transparan, jujur dan menambah kualitas dalam hal kebersamaan memajukan koperasi yang dapat menjadi bagian dari mewujudkan implementasi visi di mana para anggota dan pengurus berusaha mewujudkan visi "menjadi koperasi yang sehat, berdaya saing, tangguh dan mandiri". Kerjasama dan penyampaian informasi (komunikasi) yang baik antara anggota dan pengurus dalam mewujudkan visi dan misi koperasi dapat mengubah kinerja yang terlibat dalam pengelolaan koperasi ke arah yang lebih baik, dapat menjadi bagian dalam pengembangan dan dapat dilakukan secara bersama-sama.

Dalam mendukung informasi yang terdapat pada sistem kerja (job desk) yang diatur pada AD/ART dan dijabarkan pada tiap bagian pengurus dan anggota yang melakukan pekerjaan dalam proses keberlangsungan hidup koperasi tanpa didukung oleh teknologi (mesin). Data yang diproses serta pengambilan keputusan berdasarkan informasi dan komunikasi antar lini yang dilakukan secara akurat, tepat waktu, dapat diperbandingkan berda- sarkan karakteristik PSAK serta dapat diakses oleh seluruh anggota dan pengurus yang berhak.

Kepedulian koperasi pada masyarakat sekitar diwujudkan dengan membuka usahanya kepada masyarakat luas, namun ada hal yang tidak dapat digunakan oleh masyarakat luas di mana masyarakat hanya diperbolehkan melakukan transaksi pembelian barang kebutuhan di toko koperasi, namun ada pembatasan sebagai anggota dan bukan sebagai anggota. Sebagai anggota diperkenankan untuk simpan pinjam dan membeli di swalayan, dan bila bukan anggota hanya dapat melakukan kegiatan transaksi di toko swalayan tersebut, karena terdapat resiko bila bukan karyawan Koperasi Pegawai yang melakukan simpan pinjam.

\section{Independensi}

Prinsip independensi dapat dikatakan mandiri dalam pengelolaannya yang sejalan dengan visi menjadi koperasi yang sehat, berdaya saing, tangguh dan mandiri. Pasal 42 UndangUndang Nomor 25 Tahun 1992 menerangkan bahwa usaha koperasi merupakan usaha yang berkaitan langsung dengan kepentingan anggota untuk meningkatkan usaha dan kesejahteraan anggota. Berdasarkan kutipan tersebut kemandirian koperasi dapat dikelola secara independen dan survive dengan organisasinya sendiri, sehingga tidak ada intervensi, tidak terpengaruh oleh kepentingan tertentu, bebas dari benturan kepentingan, dari segala tekanan atau pengaruh dari pihak lain baik dari internal maupun dari eksternal, sehingga dalam pengambilan keputusan dapat dilakukan secara obyektif (KNKG, 2006). Fungsi pengurus berdasarkan tugasnya dapat dilaksa- 
nakan sesuai dengan aturan perundang-undangan yang terdapat pada AD/ART dengan penugasan melakukan RAT dan RKRAPB.

Kemandirian koperasi dapat terlihat dari kemampuan koperasi dalam menghimpun modal yang berasal dari para anggota. Koperasi dikembangkan dari, oleh dan untuk anggota. Anggota harus membiayai setiap kebutuhan investasi dalam pengembangan usaha apalagi harus mengendalikan organisasinya dan memanfaatkan pelayanan koperasi (Sugiyanto, 2013). Kemandirian koperasi memerlukan kreativitas yang tinggi untuk mengembangkan usaha dan menghasilkan laba yang tinggi. Tidak hanya kreativitas diperlukan, para pengurus dan anggota tentunya memerlukan terobosan yang inovatif dengan bekerja sama dengan pihak instansi swasta untuk dapat menjadi daya tarik bagi masyarakat dalam memenuhi kebutuhan seharihari. Tidak luput pula dalam pengembangan koperasi, pengurus perlu mengikuti pendidikan tentang koperasi dan bekerja sama antar koperasi, sebagai dasar pemahaman konsep dasar secara mendalam dan cara kerja koperasi mengembangkan diri dalam memperoleh keuntungan (laba) dan dapat mengelola koperasi dengan baik.

Pengelolaannya dilakukan secara gotong royong dan bersama-sama mewujudkan koperasi yang profesional, berdiri sendiri (otonom) dan bersifat independen serta dukungan oleh pengurus (perangkat koperasi) yang intens dan fokus dalam pengembangan berdasarkan UndangUndang Nomor 25 Tahun 1992. Independensi tersebut menurut pengurus (bendahara) sebagai berikut: "Koperasi ini dapat dikatakan mandiri karena Koperasi Pegawai ini yang telah men- jadi PNS secara otomatis akan menjadi anggota koperasi. Untuk tenaga honorer belum menjadi anggota koperasi karena belum ada penetapan menjadi PNS dari pemerintah. Modal berasal dari sumbangan anggota yang dipotong gaji setiap bulan. Dalam perjalanannya waktu dan koperasi ingin mengembangkan usaha karena modal dari anggota minim terpaksa hutang ke Bank Danamon Syariah sebesar Rp. 1.000.000.000,- dengan durasi angsuran dilunaskan selama 1 tahun. Rapat Anggota Tahunan (RAT) dilakukan bulan Maret dan Rapat Kerja Rencana Anggaran Pendapatan dan Belanja (RKRAPB) dilakukan bulan Desember untuk merencanakan pengembangan usaha dan rencana kerja tahun 2017. Dalam 2 (dua) kali kepengurusan terjadi pembatalan pemilihan ketua koperasi dikarenakan berbagai alasan sehingga pemilihan ketua dilakukan secara aklamasi dan penunjukkan langsung. Karenanya dalam melakukan pergantian pengurus tidak dilakukan secara demokrasi karena alasan tertentu”.

Pada prinsip koperasi yang terdapat pada pasal 5 ayat (1b) Undang-Undang Nomor 25 Tahun 1992 disebutkan bahwa pengelolaan dilaksanakan secara demokratis. Pengelolaan yang dilakukan secara demokratis dapat menampung berbagai saran dan ungkapan serta kepedulian anggota dalam mengembangkan koperasi secara bersama-sama tanpa intervensi pihak lain dan secara bersamasama mencari modal dari para anggota dan bekerja untuk menaikkan profit dan kesejahteraan anggota. Menurut Peraturan Menteri Negara BUMN Tahun 2011 tentang penerapan tata kelola perusahaan yang baik $(G C G)$ pasal 3 ayat (4) mengatakan bahwa 
tata kelola yang baik dapat dikelola dengan profesional tanpa benturan kepentingan dan tanpa tekanan dari pihak manapun yang tidak sesuai dengan peraturan perundang-undangan dan prinsip tata kelola. Dengan prinsip independensi pengelolaan koperasi dapat dikelola secara efisien dan efektif serta dapat memberdayakan fungsi dan meningkatkan tanggung jawab serta kemandirian pengurus koperasi.

\section{Akuntabilitas}

Prinsip akuntabilitas merupakan prinsip pertanggungjawaban struktur organisasi yang secara etis dikerjakan dalam kepengurusan setiap periode dan setiap tahun dalam rapat tahunan, seperti yang dikutip dari Prinsip $G C G$ menurut KNKG yang menyampaikan bahwa perusahaan (koperasi) dapat mempertanggungjawabkan kinerja secara transparan dan wajar serta dikelola dengan benar, terstruktur sesuai dengan kepentingan pemegang saham (anggota koperasi) maupun kepentingan lain (investor). Struktur organisasi diatur di dalam AD/ART dapat menjelaskan tugas, fungsi tiap perangkat organisasi. Kesesuaian perangkat organisasi dan tugas serta fungsi telah diatur juga pada pasal 21 di mana perangkat organisasi koperasi terdiri dari rapat anggota, pengurus dan pengawas. Rapat anggota merupakan rapat seluruh anggota dan merupakan pemegang kekuasaan tertinggi dalam koperasi untuk menetapkan anggaran dasar, rencana kerja tahun depan, mengatur kebijakan-kebijakan dari permasalahan yang terjadi di lapangan dengan mengatur kebijakan yang dikondisikan pada kasus yang ada baik di bidang usaha koperasi itu sendiri, keorganisasian serta manajemen itu sendiri.
Prinsip akuntabilitas yang digunakan untuk pengesahan pertanggungjawaban pengurus dalam melaksanakan tugasnya, pembagian SHU dan penggabungan, pembagian dan peleburan koperasi merupakan kegiatan yang telah diatur dalam AD/ART dan telah diatur menurut Undang-Undang. Tidak hanya itu saja dengan adanya kegiatan tiap periode rapat anggota berhak meminta keterangan dan pertanggungjawaban pengurus dan pengawas mengenai pengelolaan koperasi. Prinsip akuntabilitas menurut bendahara selaku pengurus sebagai berikut: "Struktur organisasi koperasi sudah diatur dalam AD/ART mengacu pada Undang-Undang Nomor 25 Tahun 1992, tidak ada perubahan dalam tugas pokoknya. Laporan pertanggungjawaban tiap tahun dilaksanakan pada saat RAT yang dilakukan bulan Maret yang dihadiri oleh seluruh anggota maupun perwakilan anggota. Perwakilan anggota hanya dikhususkan pada dosen yang bertugas di luar kota Surabaya biasanya mengirim 1-2 orang yang kebetulan ada perlu di kantor atau kondisi tidak mengajar. Pada saat rapat anggota biasanya jika ada hal yang perlu dipertanyakan berkaitan dengan kegiatan yang telah dilakukan, penggunaan keuangan walaupun sudah diaudit oleh Kantor Akuntan Publik namun ada yang bertanya dan setelah dijelaskan oleh kami (pengurus) mereka cukup dapat memaklumi. Akuntan publik tidak ikut pada saat RAT, laporan keuangan yang telah diaudit oleh KAP, pengurus yang harus mempelajari apabila ada pertanyaan, pertanyaannya paling hanya sekitar kegiatan dan yang ada di laporan pertanggungjawaban pengurus. Sejauh ini penyalahgunaan uang organisasi tidak ada hanya 
dengan berkembangnya teknologi mulai ada beberapa yang nakal contohnya gaji yang ditransfer dapat secara online diketahui, 1 jam kemudian uang setelah diambil dari ATM, padahal orang tersebut seharusnya dipotong dengan angsuran, pinjaman pokok dan lain-lain. Saat ini sudah diberlakukan pemotongan langsung angsuran maupun pinjaman yang ada".

Prinsip akuntansi menurut pengelola toko serba ada dan yang mengikuti RAT, sebagai berikut: "Job desk dari pengurus sudah diatur dalam AD/ART yang mengacu pada Undang-Undang Nomor 25 Tahun 1992. Di luar itu AD/ART dikembangkan oleh pengurus maupun anggota yang disesuaikan dengan kondisi di koperasi pegawai. Contoh SHU prinsip nominal persentasenya sama dengan Undang-Undang, prinsip pinjaman pokok, pinjaman wajib juga sama. Pertanggungjawaban dan evaluasi kerja pengurus dilakukan pada saat RAT".

Berdasarkan hasil wawancara yang dilakukan pertanggungjawaban kerja pengurus telah dilaksanakan dan dikelola dengan baik. Di mana AD/ART mengacu pada Undang-Undang Perkoperasian dan pertanggungjawaban disampaikan pada Rapat Anggota Tahunan (RAT) seperti yang telah diulas bahwa rapat tertinggi pada koperasi dilakukan pada saat RAT. Peraturan Menteri Negara BUMN Nomor PER-01/MBU/2011 tentang penerapan tata kelola perusahaan yang baik $(G C G)$ pasal 3 diatur mengenai kejelasan fungsi, pelaksanaan dan pertanggungjawaban organisasi, sehingga pengelolaan perusahaan terlaksana secara efektif. Berdasarkan peraturan menteri BUMN tersebut diakui bahwa anggota sebagai pemilik koperasi dan pengawas menginginkan pertanggungjawaban yang secara transparan dapat disampaikan dengan baik tanpa ditutup-tutupi.

Prinsip akuntabilitas merupakan prinsip yang dapat mengendalikan hubungan antar bagian dan unit-unit yang ada dengan pemberdayaan pengurus dan di-monitoring langsung oleh pengawas dan anggota koperasi, dievaluasi dan dikendalikan oleh RAT dan dapat mengurangi penyimpangan yang terjadi. Prinsip akuntabilitas menjadi prinsip perusahaan dalam sebuah misi untuk berkembang, bunyi misi yang dimiliki koperasi berbunyi bersikap adil dan demokratis serta bekerja secara transparan dan akuntabel. Menurut pedoman pelaksanaan $G C G$ (KNKG, 2006) kewajiban yang harus dilakukan oleh koperasi adalah rincian tugas dan tanggung jawab masing-masing organ perusahaan dan semua karyawan secara jelas dan selaras dengan visi, misi, nilai perusahaan dan strategi. Dari sudut pandang dan penilaian akan misi yang dimiliki bahwa koperasi ini telah mewujudkan visi dan misi tersebut dalam kehidupan dalam berorganisasi, sehingga pada masa yang akan datang koperasi tetap terus dapat semakin sehat, mandiri dan akuntabel serta berkembang.

\section{Responsibilitas}

Prinsip responsibitas merupakan dasar aturan hukum yang menjadi bagian dalam berkembangnya Koperasi Pegawai, dengan prinsip-prinsip koperasi menjadikan badan usaha yang beranggotakan seorang atau lebih berdasarkan asas kekeluargaan. Prinsip responsibilitas pada koperasi diatur pada Undang-Undang Nomor 25 Tahun 1992 pasal 5 ayat (1) dan (2) tentang prinsip koperasi yang berbu- 
nyi: prinsip koperasi diantaranya (1) keanggotaan bersifat sukarela; (2) pengelolaan dilaksanakan secara demokratis; (3) pembagian SHU dilakukan secara adil sebanding dengan besarnya jasa usaha anggota; (4) pemberian balas jasa yang terbatas terhadap modal dan kemandirian. Sifat sukarela menjadi anggota terbuka bagi siapa saja. Hanya dalam hal ini Koperasi Pegawai membatasi keanggotaannya, yaitu batasan bahwa pegawai yang masih berstatus honorer yang belum menjadi PNS tidak dapat menjadi anggota Koperasi Pegawai. Batasan itu yang menjadi alasan pegawai honorer bukan menjadi anggota koperasi. Disebutkan koperasi dilaksanakan secara demokratis sudah sesuai dengan visi dan misi Koperasi Pegawai, di mana hak suara dalam rapat dapat diwakilkan di setiap RAT.

Prinsip responsibilitas dapat juga dikembangkan pada setiap anggota masyarakat, di mana sebagai anggota masyarakat harus mematuhi peraturan dan hukum yang berlaku. Prinsip responsibilitas yang terdapat pada pedoman $G C G$ harus dipatuhi oleh perusahaan (koperasi), karena perusahaan (koperasi) harus mematuhi peraturan perundang-undangan serta melaksanakan tanggung jawab terhadap masyarakat dan lingkungan sekitar, sehingga dapat terpelihara kesinambungan usaha dalam jangka panjang. Dalam hal ini koperasi yang ada telah memenuhi aturan yang berlaku yaitu peraturan koperasi. Pada pedoman pokok pelaksanaan $G C G$ mengenai responsibilitas perusahaan (koperasi) harus berpegang pada prinsip kehati-hatian dan memastikan kepatuhan terhadap Anggaran Dasar. Perusahaan (koperasi) harus melaksanakan tanggung jawab sosial dengan peduli terhadap masyarakat dan kelestarian lingkungan terutama di sekitar perusahaan dengan membuat perencanaan dan pelaksanaan yang memadai.

Prinsip responsibilitas menurut bendahara pengurus sebagai berikut: "Sejauh ini tanggung jawab sosial kepada masyarakat hanya pada toko serba ada yang dibuka untuk umum. Rencana kerja pengelola toko serba ada tahun ini menjadikan toko bisa dipasang AC (Air Conditioner) sudah mau habis tahun kami tagih ke pengelola akhirnya sekarang dipasang $A C$ ". Sedangkan prinsip responsibilitas menurut pengelola toko serba ada sebagai berikut: "Kita membuka toko serba ada tidak hanya untuk anggota karyawan, masyarakat bisa beli dengan harga yang tidak begitu mahal, awalnya membuka toko hanya dikhususkan anggota saja”.

Berdasarkan prinsip responsibilitas pada pedoman $G C G$ diminta untuk peduli dengan masyarakat dan kelestarian lingkungan terutama di sekitar koperasi. Prinsip responsibilitas yang telah dilakukan oleh koperasi berkaitan dengan tangggung jawab sosial telah terwujud hanya saja tidak didukung dengan melestarikan lingkungan sekitar koperasi. Dari pengamatan di lapangan toko serba ada tidak begitu ramai dari pembeli (masyarakat), dikarenakan banyak yang belum peduli dengan keberadaan koperasi tersebut. Di lain pihak banyak toko kompetitor di daerah sekitar dan mini market dan hypermart yang membuat toko serba ada tidak nampak ramai.

\section{Kewajaran dan Kesetaraan (Fair- ness)}

Prinsip fairness (kewajaran dan kesetaraan) merupakan prinsip yang menekankan pada perlakuan dan ja- 
minan yang sama kepada seluruh anggota, baik yang mempunyai simpanan pokok, simpanan wajib maupun simpanan khusus (sukarela) yang dapat diambil kapan saja dengan tidak melibatkan unsur SARA dalam keanggotaan koperasi. Unsur SARA (Suku, Agama, Ras dan Antar golongan) dalam koperasi tidak dijelaskan pada Undang-Undang, namun lebih mengarah pada hak warga negara Indonesia sebagai anggota koperasi didasarkan pada kesamaan kepentingan ekonomi dalam lingkup usaha koperasi. Setiap anggota koperasi mempunyai hak dan kewajiban yang sama terhadap koperasi sebagaimana diatur dalam Anggaran Dasar (Pasal 19 ayat (1) dan (4) Undang-Undang Nomor 25 Tahun 1992). Hal yang sama disampaikan dan diatur pada Peraturan Menteri Negara BUMN Nomor: PER-01/MBU/ 2011 tentang penerapan tata kelola perusahaan yang baik pada BUMN. Prinsip fairness (kewajaran dan kesetaraan) merupakan keadilan dan kesetaraan di dalam memenuhi hak-hak pemangku kepentingan yang timbul berdasarkan perjanjian dan peraturan perundang-undangan. Pemahaman dari peneliti bahwa unsur SARA tidak diungkap pada tata kelola BUMN di mana keadilan dan kesetaraan di dalam memenuhi hak pemangku kepentingan tidak diatur di dalamnya karena akan mempengaruhi keberlangsungan hidup pada perusahaan tersebut.

Seperti yang dijelaskan oleh pengelola toko serba ada: "Jelas tidak ada unsur SARA, karena lembaga ini milik pemerintah yang tidak menonjolkan unsur tersebut, karena koperasi ini pengelolaannya diserahkan sepenuhnya kepada anggota”.

Dari kutipan tersebut menurut Arifin (2005) prinsip kewajaran lebih menekankan pada adanya perlakuan dan jaminan hak yang sama kepada pemegang saham minoritas maupun mayoritas. Dengan prinsip kewajaran keanggotaan koperasi tidak ada perlakuan secara khusus dan memiliki hakhak yang sama pada setiap anggota koperasi. Pada pedoman pelaksanaan prinsip fairness menurut $G C G$ yang diatur dalam pedoman KNKG (2006) menyatakan bahwa perusahaan memberikan kesempatan yang sama dalam penerimaan karyawan, berkarir dan melaksanakan tugasnya secara profesional tanpa membedakan suku, agama, ras, golongan, gender dan kondisi fisik. Dengan adanya prinsip yang sama berdasar hak dan kewajiban, maka semua anggota yang merupakan sumber daya manusia dapat berperan dalam perkembangan koperasi sebagai pelopor pengelolaan bisnis dan kesejahteraan masyarakat. Pengelolaan koperasi dituntut untuk lebih memberikan pelayanan kepada para anggota yang baik, dikarenakan kompetitor antara koperasi satu dengan yang lain saling berkompetisi memperoleh anggota yang loyal dalam perkembangan koperasi, dengan demikian prinsip fairness (kesetaraan dan kewajaran) pada GCG menurut KNKG (2006) memperoleh pendapat yang sama di mana pelaksanaan kegiatan perusahaan senantiasa memperhatikan kepentingan pemegang saham dan pemangku kepentingan lainnya berdasarkan asas kewajaran dan kesetaraan.

\section{Penilaian aspek-aspek Good Corpo- rate Governance pada Koperasi}

Penilaian implementasi aspek $G C G$ berdasarkan hasil angket kuesioner dan wawancara dapat ditarik kesimpulan diantaranya: 
1) Penerapan prinsip transparansi diperoleh nilai indeks 3,25 dapat terlaksana dengan baik. Transparansi pada laporan keuangan telah diaudit oleh Kantor Akuntan Publik dan secara transparan disampaikan berkaitan segala aktivitas pengelolaan keuangan selama 1 periode (satu tahun) dan disampaikan pada Rapat Anggota Tahunan.

2) Implementasi penerapan independensi diperoleh nilai indeks 3,25 dalam pengelolaannya dapat dikatakan telah dikelola dengan baik. Independensi dalam membangun koperasi dihimpun melalui modal sendiri yang berasal dari anggota dengan pengembangan diri dari, oleh dan untuk anggota, dapat membiayai kebutuhan investasi, dan mampu berkreasi serta berinovasi dalam persaingan antar koperasi serta dapat melayani masyarakat dengan baik.

3) Implementasi penerapan akuntabilitas diperoleh nilai indeks 3,00 dalam tata kelola koperasi dapat dikatakan telah dilaksanakan dengan baik. Dengan adanya $\mathrm{AD} /$ ART disertai visi, misi, maka aktivitas yang dilakukan koperasi dapat lebih terarah dan pengelolaan serta perkembangan koperasi dapat terus meningkat.

4) Implementasi penerapan responsibilitas diperoleh dengan nilai indeks 2,71 dalam tata kelola koperasi dapat dikatakan telah terlaksana dengan baik. Prinsip responsibilitas dilakukan dengan ketaatan dalam peraturan perundang-undangan di mana peraturan mengacu pada Undang-Undang Nomor 25 Tahun 1992 tentang Perkoperasian. Aturan dalam AD/ ART menjadi dasar dalam pe- ngelolaan koperasi dan telah menjadi tugas pengurus maupun anggota koperasi untuk mengimplementasikannya.

5) Implementasi penerapan Fairness (Kewajaran dan Kesetaraan) diperoleh nilai indeks dalam pengelolaan koperasi sejumlah 3,43 dengan nilai tersebut dapat dikatakan prinsip ini telah terlaksana dengan baik. Pengelolaan dan keanggotaan koperasi tidak membedakan unsur suku, agama, ras, golongan, gender dan kondisi fisik.

\section{KESIMPULAN}

Good Corporate Governance koperasi pada Koperasi Pegawai telah dilaksanakan dengan baik dengan uraian diantaranya:

a) Prinsip transparansi telah dilakukan dalam bentuk penyampaian oleh pengurus berkaitan dengan pelaporan keuangan yang telah diaudit oleh akuntan publik secara independen selama 8 tahun belakangan ini.

b) Prinsip independensi terlaksana secara baik, dengan kemandirian pengelolaan koperasi yang modalnya dihimpun dari anggota yang menjadi modal awal untuk membangun Koperasi Pegawai dalam rangka mendukung kesejahteraan anggota.

c) Pengelolaan prinsip akuntabilitas telah dapat terlaksana dengan baik, yang ditunjukkan dengan aturan yang telah ada berupa AD/ART yang di dalamnya meliputi visi dan misi serta mengacu pada UndangUndang Nomor 25 Tahun 1992 dan dibuktikan juga bahwa aturan yang berlaku telah dilaksanakan dengan baik dan dapat dikondisikan sesuai dengan kondisi koperasi. 
d) Pengelolaan prinsip responsibilitas secara sistematis mengacu pada Undang-undang Nomor 25 Tahun 1992 tentang Perkoperasian. Di samping itu setiap tahun koperasi membayar dan melaporkan pajak tepat waktu sesuai dengan tarif pajak yang berlaku untuk koperasi.

e) Tidak adanya unsur SARA dalam pengelolaan koperasi maupun dalam keanggotaan.

\section{SARAN}

Berdasarkan pengamatan di lapangan dan angket kuesioner implementasi Good Corporate Governance pada Koperasi Pegawai, maka peneliti dapat mengajukan saran yang sekiranya dapat dikembangkan di kemudian hari guna menjadi bahan pengembangan koperasi di masa yang akan datang diantaranya :

a) Pentingnya prinsip Good Corporate Governance dalam pengelolaan koperasi guna menciptakan koperasi yang memiliki standar mutu setara perusahaan dengan income yang besar.

b) Pengelolaan koperasi yang berdasarkan Good Corporate Governance memerlukan integritas yang tinggi dan etika sebagai acuan bagi koperasi dalam pelaksanaan kegiatan usaha, termasuk di dalamnya etika pemangku kepentingan guna menghindari conflict of interest.

c) Adanya pedoman perilaku yang menjadi panduan etika dalam berbisnis dalam lingkungan koperasi yang diberlakukan untuk semua anggota koperasi.

\section{DAFTAR KEPUSTAKAAN}

Arifin, 2005, Peran Akuntan dalam Menegakkan Prinsip GCG pada Perusahaan Di Indonesia (Tinjauan
Perspektif Teori Keagenan), Universitas Diponegoro.

Ferlinda, Ekky Dwi, Heru Ribawanto, Siswidiyanto, 2008, Implementasi Good Corporate Governance Dalam Meningkatkan Kualitas Pelayanan (Studi pada PT. Telkom Banyuwangi), Jurnal Administrasi Publik (JAP), Vol. 1, No. 4, hal. 2230 .

Kaihatu, Thomas S., 2006, Good Corporate Governance dan Penerapannya di Indonesia, Jurnal Manajemen dan Kewirausahaan, Vol. 8, No. 1, Universitas Kristen Petra.

KNKG, 2006, Pedoman Umum Good Corporate Governance Indonesia.

Peraturan Menteri Koperasi, Usaha Kecil dan Menengah Republik Indonesia Nomor 12/Per/M.KUKM/ IX/2015 tentang Pedoman Umum Akuntansi Koperasi Sektor Rill.

Peraturan Menteri Negara BUMN Nomor PER-01/MBU/2011 tentang Penerapan Tata Kelola Perusahaan yang Baik (GCG).

Purno, Bambang Listyo, 2013, Pengaruh Mekanisme Good Corporate Governance Terhadap Kinerja Perbankan, Skripsi, Fakultas Ekonomi, Universitas Diponegoro, Semarang.

Puspitasari, Devy Sylvia dan Unti Ludigdo, 2014, Good Governance Koperasi Wanita Serba Usaha "Setia Budi Wanita" Jawa Timur, Jurnal Ilmiah Mahasiswa, Vol. 2 No. 1, Fakultas Ekonomi Bisnis, Universitas Brawijaya, Malang.

Rakhmat, Agung dan Erwin Saraswati, 2013, Good Corporate Governance (GCG) Sebagai Prinsip Implemen- 
tasi Corporate Social Responsibility (CSR), Jurnal Ilmiah Mahasiswa, Vol. 1, No. 1, Fakultas Ekonomi Bisnis, Universitas Brawijaya, Malang.

Sugiyanto, 2013, Jati Diri Koperasi Indonesia, Proceding Seminar dan Diskusi Nasional, Institut Koperasi Indonesia.

Tadikapurry, Violetta Jingga, 2011, Penerapan Good Corporate Governance (GCG) pada PT. Bank $X$, Tbk. Kanwil $X$, Universitas Hasanuddin.

Tambunan, Tulus, 2008, Prospek Perkembangan Koperasi di Indonesia Ke depan: Masih Relevankah Koperasi Di dalam Era Modernisasi Ekonomi, Pusat Studi Industri dan UKM, Universitas Trisakti, Jakarta.
Tejo, Nurseto, 2008, Prinsip-prinsip dan Penjenisan Koperasi, Universitas Negeri Yogyakarta, Yogyakarta.

Undang-Undang Republik Indonesia Nomor 25 Tahun 1992 tentang Perkoperasian.

Wati, Like Monisa, 2012, Pengaruh Praktek Good Corporate Governance Terhadap Kinerja Keuangan Perusahaan di Bursa Efek Indonesia, Jurnal Manajemen, Vol. 1, No. 1, Universitas Negeri Padang. 